\title{
Investigating the Effect of Managers' Shift work and performance prediction on market value of shareholders ' equity in Tehran Stock Exchange
}

\author{
Navid Sadeghil \\ Maryam Khalili Araghill
}

\begin{abstract}
The market value of the shareholders' equity depends on the implementation of management policies in relation to long-term plans and it will be on the upside if executives focus on implementing these policies. If past events follow a constant process based on prior planning, performance prediction through past events will result. In some cases, the performance of managers is based on increasing their own interests and based on their personal preferences, which causes misleading information about performance prediction to be shared with stakeholders and other beneficiaries. Managers try to predict unrealistic performance in order to increase their management fees by using intermediate and virtual variables which will reduce their professional validity and ultimately lead to a reduction in the market value of the equity. The market value of the shareholders' equity is directly influenced by the conservative and courageous policies of managers. The purpose of this study is to investigate the effect of managers 'shift work and performance prediction on the market value of shareholders' equity. This research is a library and analytical-causal study and is based on the analysis of panel data (data panel). In this research, the financial information of 102 companies listed in Tehran Stock Exchange during the period of 2008-2018 (612 companies - the year) has been investigated. The results of the research show that according to the analyzes carried out in relation to the confirmation of the first hypothesis of the research, the style of managers shift working has an adverse and inverse effect on the market value of the shareholders' equity. Finally, with regard to the analysis made in relation to the confirmation of the second hypothesis of the research, we concluded that performance prediction has a positive and direct effect on the market value of the shareholders' equity.
\end{abstract}

Keywords: Managers shift working styles; Market value of the shareholders' equity; Performance prediction; Data panel

'M.Sc. Financial Management, College of Management and Economics, Tehran Islamic Azad University،Science and Research Branch, Iran navid.sadegh@gmail.com

"Department of Financial Management, College of Management and Economics, Tehran Science and Research Branch, Islamic Azad University, Tehran, Iran Corresponding Author: m.Khalili.araghi@gmail.com 


\section{Introduction}

In some cases, the style of managers' behavior is based on their personal desires and to increase their managerial interests, which will provide stakeholders and other beneficiaries with misinformation about performance prediction. In order to increase their management revenues, managers predict performance in an unrealistic way through intermediate and virtual variables, which would reduce their Professional Validity and ultimately lead to a reduction in the market value of the shareholders' equity. The market value of the shareholders' equity is directly influenced by the conservative and courageous policies of the executives and will be ascending if the implementation of these policies is to increase the interests of shareholders (Benos, E., \& Jochec, M 2011).

Managers' shift work in companies can be effective, if they lead to increased corporate profitability. The issue of supervising managers on corporate performance is one of the main tasks of managers. In order to fulfill this important task, companies have created a unit under the direct supervision of the CEO. This unit, with the supervision of the executive and operational units, provides a transparent image of the organizations to the managers. In the first part of this study, an introduction to this topic was made. In the second part, the problem is expressed and in the third section, the importance and necessity of the research, and in the fourth part, theoretical studies and in the fifth section, the hypotheses are expressed. Also, in the sixth section, the model and the analysis of descriptive statistics and correlation between variables are expressed and in the seventh part the results of the hypothesis test are explained and finally the conclusions will be expressed in the eighth section.

\section{Problem statement}

The market value of the shareholders' equity depends on the implementation of managers' policies in relation to long-term plans, and it will have a rising trend if the managers of the company have sufficient focus on applying management policies. Performance prediction through past events will result if past events follow a fixed trend 
based on prior planning (Amihud, Y., \& Goyenko, R 2013). In some cases, the style of managers 'behavior is based on their personal preferences and in order to increase their managers' interests. This causes misleading information about performance prediction to be shared with stakeholders and other beneficiaries. Managers try to predict unrealistic performance in order to increase their management fees by using intermediate and virtual variables which will reduce their professional validity and ultimately lead to a reduction in the market value of the equity. The value of the equity market is directly influenced by the conservative and courageous policies of executives and will have an upward trend if the implementation of these policies is to enhance the interests of shareholders (Benos, E., \& Jochec, M 2011). Some managers work in a shift because of their high expertise. Increasing the workload of managers in different fields, and decentralization in a particular context, will reduce their quality of performance and it also makes their long- term policies of increasing the profitability ineffective (Agarwal, Vet al 2014). One of the long-term policies of executives is to ladder capitalized costs in order to increase profitability and improve performance.

Meanwhile, with the progress of constructive projects, more investment is devoted to the projects. But, given the style of the managers' Shift work and their lack of focus in a particular activity, these policies do not reach their ultimate goal (Bessler et al 2014). Corporate executives need to decide if the identified risks associated with performance prediction are at a satisfactory level. If the level of risk is not acceptable, managers should be responsible for it. One of the most influential factors in increasing the risk in corporations is the style of shifting activities of managers (Wahal 2014). if Managers' Shift work leads to increased corporate profitability, it would be effective. One of the main responsibilities of managers is the monitoring performance of organization and in order to fulfill this important task, companies have created a unit under the direct supervision of the CEO, which provides a clear image of the organizations to the managers through the supervision of the operational and operational units (Bessler, W et al 2014). Managers offer some ways to raise market value equity. One of the ways that new investors are concerned is prediction of performance based on predetermined criteria. According to the presented issues, the main 
issue of this research is to investigate the effect of managers' shift work and performance prediction on market value of equity listed companies in Tehran Stock Exchange.

\section{Importance and necessity of research}

One of the main issues of each company is to increase the market value of its equity because the development of the company and increasing equity interests are formed on the basis of long-term managerial planning. In the complex market, with many internal and external interactions, companies that have a larger share in the capital market and attracted investors, customers, and creditors will succeed (Huang et al 2014).

With regard to managers' shift work, the implementation of policies is extremely important, and these policies will reach their ultimate goal if they are to increase the market value of equity (Elton et al 2012). For each financial period, performance prediction is important for investors and shareholders and they need to know the performance of future periods to start new investments.

The style of managers shift work is very important to shareholders of the company if this style of working leads to an increase in the market value of equity and expected performance improvement will be accepted for investors and shareholders (Müller, S., \& Weber, M 2014). In this research considering the various patterns related to the type of activity of managers, we seek to investigate the effect of managers' shift work and performance prediction on the market value of equity of listed companies in Tehran Stock Exchange.

\section{Literature review}

The present study recognizes and investigates the effect of managers 'shift work and performance prediction on market value of shareholders' equity and also provides applied bases for capital market players including potential and actual investors. Obviously, after conducting any research, the results should be used by enthusiasts and help them making 
effective decisions, so this research is the same. So the results of this research are also noteworthy for managers.

The main variables of this research are as follows:

\subsection{The shifting Style of managers' activities}

The shifting Style of managers' activities is the activity of managers in one or more different companies. Some executives work in one company and devote their entire time to the management of that company. But on the contrary, some managers are shifting in two or more companies and spend their time working in several companies (Bessler et al 2014).

\subsection{Performance prediction}

Performance prediction is prediction of the company's profitability in the coming years, according to information and events of previous years. In performance prediction, managers usually use their own experiences and company's' experience in previous years (Agarwal et al 2014).

\subsection{Market Value of equity}

Market value of equity is the total market value of the company's stock in the capital market. The market value of equity is usually based on the fluctuations of company's profitability and is also affected by fluctuations in stock returns over the long time (Wahal 2014). We will refer to some of the external and domestic research carried out on this research.

\section{Background review}

Hermann et al. (2016) in a study entitled "The style of managers' shift work, performance prediction and market value of equity" investigated the relationship between these variables. The results of their research showed that; the mode of shifting activity of managers, if changed over successive periods, affects the performance and effectiveness of the company and will increase productivity. Also, the results of their research showed that 
the market value of equity will have a positive trend through changing the style of managers' shift work.

In another study, Zahra and Pearce (2015) examined the relationship between the composition of boards of directors, corporate past performance and strategies. They concluded that there is a positive and significant relationship between the presence of nonexecutive members as the criteria for board of directors and the rate of return on assets $(R O A)$, the rate of return on equity and earning per share (EPS) as a measure of financial performance of the company.

In a study about "Composition of the boards of directors and company's performance in the Netherlands" Postma et al (2014) have shown that various variables, such as the size of the board of directors, the number of external members in board of directors and board's Rewards, play an important role in increasing the board's supervisory role.

In this research, the 94 companies listed on the Amsterdam Stock Exchange were used in eight industrial groups (mainly manufacturing), which comprises $60 \%$ of the total stock exchange holdings in Amsterdam. According to the findings of this study, there is no relationship between firm performance and board size, and, conversely, there is an inverse relationship between the number of external directors in the board and the firm's performance.

Panasian et al (2014) studied the relationship between the composition of the board of directors, the equity market value, and the performance of companies listed in the Toronto Stock Exchange. This study collects financial data for 300 major companies listed in the Toronto Stock Exchange between 2000 and 2012.In order to evaluate the company's performance, in addition to the q-tobin ratio, the indicators of the ratio of debt to assets, return on assets, and the ratio of intangibles to total assets, company size and ... have been used.

Control variables include the ratio of independent external directors to total directors, the size of the board of directors, the percentage of shares owned by board of directors, the composition of shareholders, and so on. 
The findings of this research showed that the number of external directors in public corporations has a positive impact on the company's performance.

Also, increase in the ratio of external non-executive directors to total directors to more than $50 \%$ is not significantly different from the effect of increasing this ratio at levels above $50 \%$. In addition, in this research it has been shown that increasing the number of external directors is more beneficial for companies which are likely to face whit agency conflicts. Kyereboah and Biekpe (2013) examined the relationship between some corporate governance metrics such as the size and manager's shift work and performance prediction. In this study, 16 companies were surveyed during the period 1990-2012.

Functional variables included q tobin, asset returns, and the rate of sales growth. Corporate governance variables include the size of the board of directors, the ratio of external directors to total directors and a virtual variable. If the chairman and CEO is a single person, then the virtual variable will be equal to one and otherwise equal to zero. It is noteworthy that in Ghana, the composition of the board of directors has negative and very little impact on the company's performance.

In a study Suh (2013) examined some kind of Companies with a Dual board and performance prediction system. The results of this study showed that these types of companies tend to have a larger board, but they tend to have fewer internal directors on the board. In terms of capital markets, companies with a dual board system have a higher profitability than other companies.

In a research entitled "Institutional shareholders, the Structure of Board of directors, and Corporate Performance" Tao Chen (2015) investigated the relationship between these variables. In this research, he examined how institutional shareholders influence the protection of property rights and the size and composition of the board of directors, and most of all, how the structure of the board of directors influence on the company's performance in the Chinese capital market.

Using the World Bank survey of 2,400 public and private companies in the 18 provinces of China, strong evidence was found that weaker corporations, as compared to stronger firms, have to sell their shares to government institutions and their foreign 
investment ratio connected with the structure of the board. Therefore, after controlling the influence of the complexity of institutional shareholder's influence, the opportunities of corporate growth were optimized and it became clear that the characteristics of the company's CEO and the level of his ownership, as well as the potential for endogenous concern, were factors that could reduce the efficiency and performance of companies. In addition, this research showed that if a company is in an environment with weak property rights and institutionalized shareholders' influence, the improvement of the performance of large companies will increase the independence of the board.

In a study entitled "Investigating the relationship between board responsibility, financial disclosure and internal control, shareholders' rights, CEO and board fees, external control and corporate value" Schmid, M. M., Oesch, D., \& Ammann, M. (2015) examined the relationships between these variables. The results of their research showed that there is a positive and significant relationship between board responsibility, financial disclosure and internal control, shareholders' rights, CEO and board fees, external control and corporate value.

García, M. E., \& Sánchez, B. J. P. (2015), in a study entitled "Investigating the Impact of concentration of ownership and Influence of Institutional shareholders on Corporate Value", investigated the relationships between these variables. In this study in Spain, they found that the only concentration of ownership had a significant and positive impact on the company's calculated q tubin as a measure of the company's value.

In a study titled "Investigating the Relationship between Institutional ownership and Corporate Value", Mat -Nor, F., \& Sulong, Z (2014) examined the relationships between institutional variables and corporate value. They reviewed the information of 403 companies listed on the Malaysian stock exchange, and the results showed that there is a positive and significant relationship between institutional ownership and corporate value.

Li-L in, F (2014), in a study entitled "Investigating the Impact of Institutional Ownership and Corporate Value in Taiwan," investigated the relationships between these variables on 221 Taiwanese companies between 1997 and 2006. He concluded that an increase in the 
value of companies was the result of increased control of institutional shareholders in the company.

Lee et al. (2013) in a study entitled "Investigating the information of Institutional Investors about large stocks" investigated the relationships between these variables. They have stated that ordinary investors believe: Institutional investment behavior is more informed, and in particular, their investment in large stocks contains more information and with the presence of institutional investors, the speed of adjusting stock prices increases.

Kanellos, T. S. \& K. George (2008) in a study entitled "Investigating the Relationship between Corporate Governance and Corporate Performance", with the special economic conditions of Greece in 314 companies in a period of two years, examined the relationships between these variables. In this research, they categorized companies from corporate governance into three categories:

- Companies that have good democracies in making decisions process

- Companies that are partly democratic in making decisions process

- Companies that lack democracy in the decision-making process.

The results of their research proved that companies with more democracy are performing better.

In a research, Shariat Pahaie (2015), based on the theory of representation, has evaluated the prediction of corporate performance and controlling the behavior of managers. The statistical population of this research was composed of 100 joint stock companies and in order to evaluate company's performance the $q$ tobin's financial variable had been used. In this research, he examined the relationship between the seven mechanisms for controlling the manager's performance and functional variables and failed to achieve a meaningful relationship between ownership and corporate performance.

In another study Ahmadvand (2015) examined the effect of managers' shift work on the performance of listed companies in Tehran Stock Exchange. Independent variables including corporate governance variables and dependent variables were also related to functional variables. The industry factor was also considered as a control variable. In this research, a one-factor analysis of variance and multi-factor analysis of variance were used. 
The results showed no significant relationship between corporate ownership and performance. Based on the results, with the increase in the number of major shareholders, the ROE also increases, which implies the impact of supervision and control by major shareholders. Although this relationship is not significant, the smaller the number of major shareholder companies, the P / E coefficient is less and more desirable.

In another study by Qalibaf Asl and Rezaei (2014), the effect of board composition on the performance of 72 companies listed in Tehran Stock Exchange during the period of 2005-2003 was investigated. In this research, the proportion of non-executive members in the board of directors is considered as an independent variable of the board composition and the company's performance is measured as an associated variable through several criteria like the rate of return on equity, net margin, gross margin, average sales growth and average net profit growth. The control variables in this research included company size, financial leverage, and industry. All hypotheses have been tested by multiple regression analysis and stepwise regression analysis. Tests showed that there is not a meaningful relationship between the ratio of non-executive members and none of the performance criteria.

Another research was carried out by Ghanbari (2014), which explores the impact of corporate governance mechanisms on the performance of companies listed in Tehran Stock Exchange. Functional variables included net profit growth and $\mathrm{q}$ tobin, and governance variables included three variables: number of non-executive members of the board, internal audit, and information transparency. In order to test the hypotheses two statistical methods have been used: Multiple regression method, Spearman correlation coefficient. According to the research findings, none of the relationships between the three independent variables and the firm's performance were significant.

Bonab (2013) considered the composition of the board as one of the company's corporate governance criteria and examined the relationship between this variable and the market value of equity of companies listed in Tehran Stock Exchange. In this research, the governance variables include the percentage of non-executive directors and the role of management combination. In this research, return on assets, return on equity and earnings 
per share are used as functional variables. The results of the research indicated that there was no significant relationship between the factors related to the composition of the board of directors and the functional factors of the companies. This means that there is no relationship between the composition of the board of directors and the performance of companies listed in Tehran Stock Exchange.

In another study by Nickbakht et al. (2013), variables such as the size of the board of directors, the ratio of non-executive members to the composition of the board, the number of board meetings, the financial knowledge of board members, and the separation of the role of the director from the chairman of the board of directors and the impact of these variables has been measured on the company's performance prediction. In this research, the rank firms' performance is calculated based on 5 factors. These factors include: income growth, operating profit growth, net profit growth, return on assets and return on equity. According to previous research, company size and financial leverage were considered as control variables. In this research, the information of 71 companies listed in the stock exchange were collected during the period of 2008 to 2018 and analyzed by Spearman correlation coefficient and regression analysis.

The results of this study showed that the board of directors in the Iran's capital market failed to fulfill its duties effectively to reduce agency conflicts and have no effect on the company's performance.

In another study by Arab Mazar and Taherkhani (2012), the factors related to the composition of the board of directors and their impact on corporate performance was examined. Based on the results of measuring the six hypotheses presented in this study, it was revealed that the corporate governance variables including the number of board members and the number of non-executive directors and the number of major shareholders had no effect on the return on equity, but on the other hand, these variables are effective on $q$ tubin. The results of this research showed that the number of board members has a little and negative impact on $q$ tobin, but the number of non-executive members of the board of directors and the number of major shareholders have a positive and, of course, little impact on q tobin. 
Kurdistani and Abashi (2014), in a study entitled "Investigating the Impact of Customer Focus on Corporate Financial Performance", using the financial information of 79 companies listed in the Tehran Stock Exchange between 2002 and 2011, investigated the relationships between these variables. The sample number includes 790 companies a year. The findings show that customer focus is positively correlated with financial performance, which is statistically significant. Therefore, increasing customer focus improves corporate financial performance. Companies with high customer focus also experience better inventory management. The findings of this study support the importance of having major customers in the market.

Khan Mohammadi and Gharehdaghie (2014) conducted a research entitled "Comparative Study of the Performance of Entities Issued Before and After Delegation Based on the EFQM Model and some Financial Indicators". In this study they have investigated the relationships between the variables of corporate performance. In this research, data were collected through a questionnaire and interview with companies. Then, the data are rated and ranked using the organizational excellence model of quality management in three criteria (financial, productivity, and employment).

Then, in order to prove the claims of corporations, their financial rating has been evaluated through the information available on the stock exchange and using indicators such as Q tobin, Market Value Added, return on Equity, Return on capital and Financial Ratios. Thus, the accuracy and the difference between the claims made by the companies and the stock exchange were specified. The overall average of indicators indicates that all variables have experienced an improvement of $43 \%$ in performance in comparison to preassignment.

Mahdavi and Ghorbani (2012) have conducted a research entitled "Comparative Study of New and Traditional Liquidity Indicators and investigating the Role of these indicators in Assessing the Financial Performance of Companies listed in Tehran Stock Exchange". In this study, they investigated the relationship between the new and traditional indicators of liquidity and financial performance evaluation over an 11-year period from 2008 to 2018 in 74 companies listed in Tehran Stock Exchange. 
Their research method was correlation and using multiplied regression. Based on the results, all the research hypotheses have been confirmed, except the hypotheses related to the Tobin Q ratio.

Moradi and Rostami (2012) have done a research entitled "Investigating the Relationship between Corporate Governance Mechanisms and Company Performance after Initial Delivery: Evidence from Companies Accepted in Tehran Stock Exchange". In this research, they investigated the relationships between these variables using the financial information of 70 companies listed in the Tehran Stock Exchange between 2002 and 2008. Their research sample includes 490 company - year. Findings show that institutional ownership and managerial ownership have a positive relationship with the performance of companies after initial publication. In addition, the presence of non-executive directors improves the company's performance. However, there is no relationship between the dual role of CEO and company's performance.

Moradzadeh Fard et al. (2012), in a study entitled "Investigating the effect of board rewards and institutional ownership on earnings management in companies listed to the Tehran Stock Exchange", investigated the relationship between variables for the period from 2005 to end of 2009 using Jones Modified Model. Their research results showed a negative relationship between institutional ownership of shares and earnings management. In other words, with the increase in the percentage of institutional ownership, the firm's flexibility to manage accruals decreases. In addition, the results indicate that there is a direct relationship between the board rewards and earnings management.

\section{Research hypotheses}

According to theoretical foundations and researches, the hypotheses of this research are presented as follows:

Main hypothesis 1: The style of managers' shift work affects the market value of equity. Main hypothesis 2: Performance prediction effects on the equity market value of equity.

\section{Research methodology}


This research is a correlation research and in terms of purpose, it is a type of functional research.

The research project is also semi-experimental because it uses historical data. The statistical population of this research includes all companies listed in Tehran Stock Exchange during the period from 2010 to 2015 . The research sample includes companies that have been admitted to the Tehran Stock Exchange by the end of 2009, so that their financial period ends by the end of March, during the research period, there is no change in the financial year, and the data required for conducting this research Available. Based on constraints, 102 companies have been selected as the final sample of research.

The information and data required have been collected through the official sites of Tehran Stock Exchange, including the site of Rdis, Research and Development Agency, the Information Exchange Agency and the newly developed software. The basic calculation required has done in Excel spreadsheet. The final analysis was done using Eviews 7, SPSS 20 and Minitab 16 software. To test the hypothesis of the research, multiple regression model and data panel method were used. The research models derived from Hermann et al. (2016) have been estimated as follows:

Model related to the first hypothesis of research:

$\alpha_{i, t}=\alpha_{0}+\beta_{1}$ Style $_{l, t}+\beta_{2}$ Expenses $_{, t}+\beta_{3}$ Turnover $_{, t}+\beta_{4} \log (T N A)_{i, t}+\beta_{5}$ FundAge $_{, t} / 100$

$+\beta_{6}$ Time $_{i, t}+\beta_{7} D_{i, t}+\varepsilon_{\mathrm{i}, \mathrm{t}}$

Model related to the second hypothesis of research:

$\alpha_{i, t}=\alpha_{0}+\beta_{1}$ Activity $_{, t}+\beta_{2}$ Expense $_{t, t}+\beta_{3}$ Turnovęr, $+\beta_{4} \log (T N A)_{i, t}+\beta_{5}$ Fund Age $_{t, t} / 100$

$+\beta_{6}$ Time $_{i, t}+\beta_{7} D_{i, t}+\varepsilon_{\mathrm{i}, \mathrm{t}}$

\section{Results}

Test Results the first hypothesis 
The purpose of the first hypothesis is to investigate the effect of managers' shift work and performance prediction on the market value of the equity. The statistical hypothesis is defined as follows:

H0: The style of managers' shift work does not affect the market value of equity. H1: The style of managers' shift work affects the market value of equity.

This hypothesis is estimated using model (1) as a panel data and will be approved if the coefficient $\beta_{1}$ is significant at $95 \%$ confidence level.

$$
\begin{aligned}
& \alpha_{i, t}=\alpha_{0}+\beta_{1} \text { Style }_{i, t}+\beta_{2} \text { Expenses }_{,, t}+\beta_{3} \text { Turnover }_{r, t}+\beta_{4} \log (T N A)_{i, t}+\beta_{5} \text { FundAge }_{\ell, t} / 100 \\
& +\beta_{6} \text { Time }_{i, t}+\beta_{7} D_{i, t}+\varepsilon_{\mathrm{i}, t}
\end{aligned}
$$

$$
\left\{\begin{array}{l}
H_{0}: \beta_{1}=0 \\
H_{1}: \beta_{1} \neq 0
\end{array}\right.
$$

To determine if the panel data approach is useful in estimating the model, it is necessary to test the chow test or $\mathrm{F}$ and to determine which method (fixed effects or random effects) is more suitable for estimation (diagnosis The constant or randomness of the differences between the unit sections (Hausman test) is used. The results of these tests are presented in Table 1.

Table 1 - Chavo and Hausman test results for model (1):

\begin{tabular}{c|c|c|c|r|c}
\hline Test & Number & Statistic & $\begin{array}{l}\text { Statistic } \\
\text { value }\end{array}$ & $\begin{array}{r}\text { Degrees } \\
\text { of freedom }\end{array}$ & $\begin{array}{c}\text { P- } \\
\text { Value }\end{array}$ \\
\hline Chow & 612 & $F$ & $2 / 8588$ & $(503 ، 101)$ & $0 / 0050$ \\
\hline Hausman & 612 & $\chi^{2}$ & $2 / 8767$ & 2 & $0 / 0062$ \\
\hline
\end{tabular}

Based on the results of Chow test and its P-value (0.0050), the test H0 hypothesis has been rejected at $95 \%$ confidence level, indicating that panel data can be used. Also, according to the results of the Hausman test and its P-value (0.0062) which is less than 0.05, the test $\mathrm{HO}$ hypothesis is rejected at the $95 \%$ confidence level and the $\mathrm{H} 1$ hypothesis is verified. Therefore, it is necessary to estimate the model using constant effects method. 
In addition to examining the absence of the coherence between the independent variables introduced in the model, in order to evaluate the validity of the model and in order to examine the assumptions of classical regression it is necessary to test also the normality of the residuals, the consistency of the variances, the independence of the residuals and the absence of a model specification error.

To test the normalization of error sentences, various tests can be used. One of these tests is the Jarque-Bera test, which is used in this study.

The results of the Jarque-Bera test indicate that the residuals from the estimation of the research model have a normal distribution at $95 \%$ confidence level, so that the probability of this test $(0.5841)$ is greater than 0.05 . Another statistical assumption of classical regression is the equivalence of variance of the remainder. If the variances are heterogeneous, the linear estimator is not unbiased and does not have the least variance. In this study, Breusch and A. R. Pagan test was used to check the consistency of variances. Given the significance level of this test, which is less than 0/05 (0.0221), the zero hypothesis is based on the existence of the equivalence of variance rejected and it can be said that the model has a heterogeneous variance problem. In this study, the generalized least squares estimation (GLS) method has been used to solve this problem. In this study, the DurbinWatson (D-W) test was used to test the non-correlation of residuals, which is one of the assumptions of regression analysis and is called correlation.

According to the preliminary results of estimating the model, the value of the DurbinWatson is 2.41, and since it is between 1.5 and 2.5, it can be concluded that the remainders are independent of each other. In addition, to test whether the model has a linear relationship and whether the model of the research in terms of linearity or non-linear relationship is properly explained, a Ramsy test is used. Considering that the significance level of the Ramsy test (0.3141) is greater than 0.05 , therefore the zero hypothesis of this test is verified based on the linearity of the model and the model does not have an error specification. The results of the above tests are summarized in Table 2.

Table 2 - Results of tests related to statistical assumptions of model (1) 


\begin{tabular}{|c|c|c|c|c|c|c|}
\hline \multicolumn{2}{|c|}{$\begin{array}{l}\text { Jarque-Bera } \\
\text { Statistic }\end{array}$} & \multicolumn{2}{|c|}{$\begin{array}{c}\text { Breusch-Pagan } \\
\text { Statistic }\end{array}$} & \multirow{2}{*}{$\begin{array}{c}\text { Durbin- } \\
\text { Watson } \\
\text { Statistic } \\
\text { D }\end{array}$} & \multicolumn{2}{|c|}{ Ramsey Statistic } \\
\hline$\chi^{2}$ & $P$-Value & $F$ & P-Valuє & & $F$ & P-Value \\
\hline $1 / 6296$ & $0 / 5841$ & $2 / 3581$ & 0/0221 & $2 / 41$ & $1 / 1603$ & $0 / 3141$ \\
\hline
\end{tabular}

According to the results of Chow and Hausman tests as well as the results of the test of statistical assumptions of classical regression, model (1) of the research is estimated using the panel data method as a constant effect. The estimated model results are presented in Table 3. The estimated shape of the model using the Eviews 7 software will be as follows:

$\alpha_{i, t}=0.2894-0.0133$ Style $e_{i, t}-0.0531$ Expleses $_{l, t}+0.0304$ Turnover $_{i, t}+0.8800 \log (T N A)_{i, t}$

+0.0067 FundAge $e_{, t} / 100+0.9300$ Time $_{i, t}-0.0143 D_{i, t}+\varepsilon_{\mathrm{i}, \mathrm{t}}$

Table 3 - Test results of the first hypothesis of the research using the fixed effects method

\begin{tabular}{|c|c|c|c|c|c|}
\hline \multicolumn{5}{|c|}{ Dependent variable: market value of the Equity } & * \\
\hline \multicolumn{5}{|c|}{ Number of sections selected: 102} & ** \\
\hline \multicolumn{5}{|c|}{ Total number of observations per year - Section: 612 years - Company } & *** \\
\hline \multicolumn{5}{|c|}{ Estimated statistical method: Data panel - GLS fixed effects } & $* * * *$ \\
\hline \multicolumn{5}{|c|}{ Years reviewed: 2011-09 } & $* * * * *$ \\
\hline \multicolumn{6}{|c|}{$\checkmark \checkmark \checkmark$ Cross-section fixed (dummy variables) ${ }^{* * * * *}$} \\
\hline $\begin{array}{l}\text { Variable } \\
\text { title }\end{array}$ & $\begin{array}{c}\text { Sign of } \\
\text { Variable }^{* * *}\end{array}$ & Coefficient*** & $\begin{array}{c}\text { ***T} \\
\text { statistic }\end{array}$ & $\begin{array}{l}* * * \mathbf{P}- \\
\text { Value }\end{array}$ & $\begin{array}{c}\text { Relationship } \\
* * *\end{array}$ \\
\hline $\begin{array}{c}\text { Fixed } \\
\text { component }\end{array}$ & $\mathrm{C}$ & $0 / 2894$ & $3 / 1968$ & 0/0015 & Positive \\
\hline $\begin{array}{l}\text { managers } \\
\text { Shift work } \\
\text { model }\end{array}$ & Style $_{i, t}$ & $-0 / 0133$ & $-3 / 8210$ & 0/0120 & Negative \\
\hline $\begin{array}{c}\text { Capital } \\
\text { expenditure }\end{array}$ & Expenses $_{i, t}$ & $-0 / 0531$ & $-4 / 0335$ & 0/0018 & Negative \\
\hline
\end{tabular}




\begin{tabular}{|c|c|c|c|c|c|}
\hline $\begin{array}{l}\text { Current } \\
\text { ratio }\end{array}$ & Turnover $_{i, t}$ & $0 / 0304$ & $5 / 6314$ & 0/0081 & Positive \\
\hline $\begin{array}{l}\text { size of } \\
\text { company }\end{array}$ & $\log (T N A)_{i, t}$ & $0 / 8800$ & $0 / 0026$ & 0/9979 & meaningless \\
\hline $\begin{array}{l}\text { Age of } \\
\text { the } \\
\text { company }\end{array}$ & FundAge $_{i, t} / 100$ & $0 / 0067$ & $6 / 1428$ & 0/0004 & Positive \\
\hline $\begin{array}{l}\text { Income } \\
\text { ratio }\end{array}$ & Time $_{i, t}$ & $0 / 9300$ & $0 / 0137$ & $0 / 9890$ & meaningless \\
\hline $\begin{array}{l}\text { profit } \\
\text { sharing }\end{array}$ & $D_{i, t}$ & $-0 / 0143$ & $-3 / 8862$ & 0/0059 & Negative \\
\hline \multicolumn{6}{|c|}{$\checkmark \checkmark \checkmark$ Linear estimation after one-step weighting matrix ${ }^{\star * \star * *}$} \\
\hline *** & \multicolumn{4}{|c|}{ Coefficient determination of model } & $0 / 4525$ \\
\hline$* \star * * \star$ & \multicolumn{4}{|c|}{ Modified Coefficient determination of model } & $0 / 3893$ \\
\hline 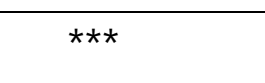 & \multicolumn{4}{|l|}{$F$ statistic } & $2 / 8385$ \\
\hline 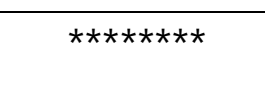 & \multicolumn{4}{|l|}{$(P-$ Value $)$} & $(0 / 0001)$ \\
\hline * & \multicolumn{4}{|c|}{ *Significance level $\% 95$} & $P \geq 95 \%$ *** \\
\hline ** & \multicolumn{4}{|l|}{$* \star \%$ statistic } & $P \leq 5 \% * * *$ \\
\hline
\end{tabular}

In the study of the significance of the whole model, given that the probability of $\mathrm{F}$ statistics is less than $0.05(0.0120)$, with $95 \%$ confidence, the overall model's significance is confirmed.

The coefficient of model determination also indicates that $45.25 \%$ of the market value of equity is explained by the variables entered in the model. Considering the significance of the coefficients according to the results presented in Figure 4-7, the probability of $t$ for the variable coefficient of lightness of shift work of managers is less than 0.05 (0.120), as a result of the existence of a significant relationship between the style of shift work of managers and the market value of the equity is confirmed at $95 \%$ confidence level. 
Therefore, the first hypothesis of the research is verified and with $95 \%$ confidence it can be said that there is a meaningful relationship between the style of managers 'shift work and the market value of shareholders' equity.

The negative coefficient of this variable $(-0.0133)$ suggests an inverse relationship between the style of managers' shift work and the market value of their shareholders' equity, so that with the increase by 1 unit of managers' shift work, the market value of the equity is also reduced by 0.1333 units.

Therefore, according to analyzes carried out related to the verification of the first hypothesis of the research, it can be concluded that the style of managers' shift work has a negative and inverse effect on the market value of the shareholders' equity.

\subsection{Test Results of second hypothesis}

The purpose of the second hypothesis test is to investigate whether performance prediction affects the market value of a firm's equity market. And its statistical hypothesis is as follows:

H0: Performance prediction does not affect the value of the equity market of the companies.

H1: Performance prediction affects the market value of equity firms.

This hypothesis is estimated using the model (2) as panel data and will be approved if the coefficient is significant at $95 \%$ confidence level.

$\alpha_{i, t}=\alpha_{0}+\beta_{1}$ Activity $_{i, t}+\beta_{2}$ Expenses $_{, t}+\beta_{3}$ Turnover $_{t, t}+\beta_{4} \log (T N A)_{i, t}+\beta_{5}$ FundAge $_{t, t} / 100$

$+\beta_{6}$ Time $_{i, t}+\beta_{7} D_{i, t}+\varepsilon_{\mathrm{i}, \mathrm{t}}$

$$
\left\{\begin{array}{l}
H_{0}: \beta_{1}=0 \\
H_{1}: \beta_{1} \neq 0
\end{array}\right.
$$

The results of the Chow tests (to determine the use of the panel or combination data method) and Hausman(to specify the use of the static or random effects method in panel data method) for model (2) are presented in Table 4.

Table 4 - Chavo and Hausman test results for model (2): 


\begin{tabular}{c|c|c|c|c}
\hline Test & Static & Statistic value & $\begin{array}{l}\text { Degrees of } \\
\text { freedom }\end{array}$ & P-Value \\
\hline Chow & $F$ & $1 / 8472$ & $(503,101)$ & $0 / 0461$ \\
\hline Hausman & $\chi^{2}$ & $3 / 4337$ & 7 & $0 / 0022$ \\
\hline
\end{tabular}

Based on the results of Chow test and its P-Value (0.461), the test $\mathrm{H} 0$ hypothesis was rejected at $95 \%$ confidence level, indicating that panel data can be used. Also, based on the results of the Hausman test and its P-Value (0/0000) which is less than $0 / 05$, the test $\mathrm{H} 0$ hypothesis is rejected at the $95 \%$ confidence level and the $\mathrm{H} 1$ hypothesis is verified. Therefore, it is necessary to estimate the model using the static effects method. In examining the classical regression assumptions, the Jarque-Bera's test results also indicate that the residuals from the estimation of the research model have a normal distribution at $95 \%$ confidence level. Considering the significance level of the Pagan test, which is smaller than 0.05 (0.0219), the zero hypothesis, namely, the existence of the variance equivalence, has been rejected and it can be said that the model has a heterogeneous variance problem. In this hypothesis, an estimation of generalized least squares (GLS) has been used to solve this problem.

In the self-correlation test, the model residuals performed using the D-W statistic were 2.9 and 2.8, respectively, and it can be concluded that the residuals are independent. In addition, considering that the significance level of the Ramsey test is greater than 0.05 (0.204), therefore, the zero hypothesis of this test, which indicates that the model is linear, is verified and the model does not have a specification Error.

The summary of the results of the above tests is presented in Table 5.

\begin{tabular}{|c|c|c|c|c|c|c|}
\hline \multicolumn{2}{|c|}{$\begin{array}{l}\text { Jarque-Bera } \\
\text { Statistic }\end{array}$} & \multicolumn{2}{|c|}{$\begin{array}{c}\text { Breusch-Pagan } \\
\text { Statistic }\end{array}$} & \multirow{2}{*}{$\begin{array}{c}\begin{array}{c}\text { Durbin- } \\
\text { Watson } \\
\text { Statistic }\end{array} \\
\text { D }\end{array}$} & \multicolumn{2}{|c|}{ Ramsey Statistic } \\
\hline$\chi^{2}$ & P-Value & $F$ & P-Value & & $F$ & P-Value \\
\hline
\end{tabular}




\begin{tabular}{|l|l|l|l|l|l|l}
\hline $1 / 4390$ & $0 / 3412$ & $2 / 3612$ & $0 / 0219$ & $2 / 29$ & $0 / 2504$ & $1 / 3880$ \\
\hline
\end{tabular}

According to the results of Chow and Hausman tests as well as the results of the test of statistical assumptions of the classical regression, model (2) of the research is estimated using the panel data method as a fixed effect. The model estimation results are presented in Table 6.

Table 6: Test results the second hypothesis of the research using the fixed effects method

Dependent variable: Equity market value

Number of observations: 612 years - company

Estimated statistical method: Data panel - GLS fixed effects

Years reviewed: 2011-09

\begin{tabular}{|c|c|c|c|c|c|}
\hline Variable title & $\begin{array}{l}\text { Sign Of } \\
\text { Variable }\end{array}$ & Coefficient & $\begin{array}{c}\mathbf{t} \\
\text { Statistic }\end{array}$ & $\begin{array}{r}\text { P- } \\
\text { Value }\end{array}$ & Relation \\
\hline $\begin{array}{c}\text { Fixed } \\
\text { component }\end{array}$ & C & $0 / 3108$ & $3 / 4164$ & $0 / 0007$ & Positive \\
\hline $\begin{array}{l}\text { Performance } \\
\text { prediction }\end{array}$ & Activity $i, t$ & $0 / 0382$ & $2 / 9669$ & $0 / 0341$ & Positive \\
\hline $\begin{array}{c}\text { Capital } \\
\text { expenditure }\end{array}$ & $\begin{array}{l}\text { Expenses } \\
i, t\end{array}$ & $0 / 0511$ & $3 / 9927$ & $0 / 0013$ & Positive \\
\hline Current ratio & $\begin{array}{l}\text { Turnover } \\
\text { i,t }\end{array}$ & $-0 / 0335$ & $-0 / 6935$ & $0 / 4883$ & meaningless \\
\hline $\begin{array}{l}\text { size of } \\
\text { company }\end{array}$ & $\begin{array}{l}\log (\mathrm{TNA}) \\
i, t\end{array}$ & $0 / 0012$ & $2 / 0700$ & $0 / 0442$ & Positive \\
\hline $\begin{array}{l}\text { Age of the } \\
\text { company }\end{array}$ & $\begin{array}{l}\text { Fundage } \\
\mathrm{i}, \mathrm{t} / 100\end{array}$ & $-0 / 0021$ & $-0 / 0462$ & $0 / 9631$ & meaningless \\
\hline Income ratio & Time $_{i, t}$ & $0 / 0003$ & $4 / 1207$ & $0 / 0039$ & Positive \\
\hline profit sharing & $\mathrm{D}_{i, t}$ & $0 / 0102$ & $4 / 6513$ & $0 / 0002$ & Positive \\
\hline \multicolumn{5}{|c|}{ Coefficient determination of model } & $0 / 6514$ \\
\hline \multicolumn{5}{|l|}{$\begin{array}{l}F \text { Statistic } \\
(P-\text { Value })\end{array}$} & $\begin{array}{c}3 / 4851 \\
(0 / 0000)\end{array}$ \\
\hline
\end{tabular}


The estimated shape of the model using Eviews software 7 will be as follows:

$\alpha_{i, t}=0.3108+0.0382$ Activity $_{, t}+0.051$ Expense $_{t, t}-0.0335$ Turnovę, $_{i, t}+0.0012 \log (T N A)_{i, t}$ -0.002 Fund Age $_{l, t} / 100+0.0003$ ime $_{l, t}+0.0102 D_{i, t}+\varepsilon_{i, t}$

In the study of the significance of the whole model, given that the probability of the $\mathrm{F}$ statistic is smaller than 0.05 (3.4851), with a confidence level of $95 \%$, the significance level of the total model is confirmed. The model's coefficient of determination also indicates that $65.14 \%$ of the market value of the equity is explained by the variables entered in the model. In the study of the significance of the coefficients, considering the results presented in Figure 4-10, since the probability of $t$ static for the coefficient of performance prediction variance is smaller than $0.05(0.314)$, there is a significant relationship between the performance prediction and market value of the equity is approved at 95\% confidence level. Therefore, the second hypothesis is verified and with $95 \%$ confidence it can be said that there is a significant relationship between the performance prediction and market value of the equity. The positive coefficient of this variable (0.0382) suggests a direct relationship between the performance prediction and the market value of equity, so with the increase in performance prediction by 1 unit, the market value of equity will increase by $0.382 \%$. Therefore, according to analyzes carried out in relation to the confirmation of the second hypothesis, it can be concluded that performance prediction has a positive and direct effect on market value of the equity.

\section{Discussion and Conclusion}

In this research, the descriptive statistics of the research variables were first presented. In the following, inferential statistics were presented and the research models were presented in the form of inferential statistics of the hypotheses. To test the research models, 
the Chaow test was first used to determine whether the panel method should be used or the mixed method. In the following, the Hausman test was used to use the random effects or fixed affects method.

Finally, the Goodness-of Fit Index and the results of the classical regression assumptions for the research models were expressed. In this research, two main hypotheses were studied.

In the first hypothesis, the effect of the manager's shift work style on the market value of shareholders' equity was reviewed. The result of this hypothesis test showed that the manager's shift work style has a negative and inverse effect on market value of the equity. The results of the first hypothesis of the research are consistent with some of the previous studies, including Agarwal, Vet al (2014), Bessler et al (2014), and Müller, S., \& Weber, M (2014), and with the results of the research by Elton et al (2012) and Mier \& Rambuts (2009) Contradicts.

In the second main hypothesis, the effect of performance prediction on market value of the equity was examined.

The test result of this hypothesis suggests that performance prediction has a direct and positive effect on market value of the equity.

The results of this hypothesis are consistent with many research findings, including Amihud, Y., \& Goyenko, R (2013), Wahal (2014) and Bessler, W et al. (2014).

Finally, with regard to the analysis made in relation to the confirmation of the second hypothesis of the research, we concluded that performance prediction has a positive and direct effect on the market value of the shareholders' equity.

\section{References}

Ahmadvand, Jila. (2011). "Investigating the Effect of Ownership Structure on the Performance of Companies listed in Tehran Stock Exchange", Master's thesis, Al-Zahra University, Tehran. 
Arab Mazar Yazdi, Taherkhani. (2015). "The Effect of Board Composition on the Performance of Companies listed in Tehran Stock Exchange", Journal of Accounting Studies No. 29, Spring 2011

Benos, E., \& Jochec, M. (2011). Short term persistence in mutual fund market timingand stock selection abilities. Annals of Finance, 7, 221-246.

Bessler, W., Blake, D., Lückoff, P., \& Tonks, I. (2014). Why is persistent mutual fundperformance so difficult to achieve? The impact of fund flows and manager turnover.Working Paper.

Boyd,B.K. (2012). CEO duality and firm performance: A contingency model. Strategic Management Journal, 16, 301-312.

Elton, E., Gruber, M., \& Blake, C. (2012). An examination of mutual fund timing ability using monthly holdings data. Review of Finance, 16(3), 619-645.

Hosseini, Mojtaba. (2007). "Investigating the Effect of Institutional Ownership as A Corporate Governance Measures on the Returns of Shareholders of Companies listed in Tehran Stock Exchange" Master's thesis, University of Tehran

Huang, J., Sialm, C., \& Zhang, H. (2011). Risk shifting and mutual fund performance.Review of Financial Studies, 24(8), 2575-2616.

Izadiya, Nasser and Mobasheri, Mehdi. (2014). "Investigating the Correlation Determination of Intellectual Capital Resources and Their Impact on the Value of Companies listed in Tehran Stock Exchange", Journal of Financial Accounting. Year 6, No. 24, winter 2014, p. 40-22.

Karami, Gholamreza. (2008). "Investigating the Relationship between Institutional Owners and the Information Content of Profit", Accounting and Auditing Reviews, The fifteenth course, Num 54, Pages 81-100 
Khan Mohammadi, Mohammad Hamed and Gharadaghi, Ali Akbar. (2014). "A Comparative Study of the Performance of Entities Issued Before and After Depositing Based on the EFQM Model and Some Financial Indices", Audit Knowledge Journal, 2014, No. 57, Winter 2014.

Kyereboah Coleman, A and Biekpe, N. (2011). "The relationship between board size, board composition, CEO duality and firm performance: experience from Ghana", Corporate Ownership and Control Journal, Vol.4.

Moradzadeh Fard, Mehdi; Zarezadeh Mehrizi, Mohammad Sadeq and Taker, Reza. (2012). "Investigating the effect of board rewards and institutional ownership on earnings management in companies listed in Tehran Stock Exchange", Journal of Tehran Stock Exchange

Müller, S., \& Weber, M. (2014). Evaluating the rating of Stiftung Warentest: Howgood are mutual fund ratings and can they be improved? European Financial Management, 20(2), 207235.

Nikbakht, Seyedi, Hashem al-Husseini. (2014). "Investigating the Impact of Board's Features on Corporate Performance", Journal of Accounting Progress of Shiraz University, No. 1, summer 2014.

Panasian, C, Prevost, A.K, and Bhabra, H.S. (2014). Board composition and firm performance: the case of the Dey report and publicly listed Canadian firms, working paper, Department of Finance, Montreal University, Montreal, Canada.

Postma, Th. J.B.M, Ees, H, van and Sterken, E. (2012). "Board composition and firm performance in the Netherlands", University of Groningen, Research Institute SOM (Systems, Organisations and management).

Salimi, R. (2014). "The Relationship between the role of the board of directors in designing strategic management and financial performance of the company", Master's thesis, Allameh 
Tabataba'i University.

Schmid, M. M., Oesch, D., \& Ammann, M. (2015). Corporate governance and firm value: nternational evidence. Journal of Empirical Finance, 18(3), 36- 55

Suh, S. (2013). The Characteristics of a Classified Board and the Effects of the Board on Earnings Quality, Accounting Conservatism, and Credit Risk. Unpublished PhD Dissertation, Graduate School of Syracuse University.

Tehrani, Reza-Khojestat, Mohammad Ali. (2008). "The Relationship between Capital Productivity and Future Stock Returns and Its Influence on Value and Development Investment Strategies", The Manuscript of Management Science of Iran, Third Year, No. 11,

Ulf Herrmann, Martin Rohleder, Hendrik Scholz. (2016). Does style-shifting activity predict performance? Evidence from from equity mutual funds from equity mutual funds.

Victor-Octavian Müller. (2014). The impact of board composition on the financial performance of FTSE100 constituents, Procedia - Social and Behavioral Sciences 109, 969 975.

Wahal, S. (2014). Investing in a global world. Review of Finance,18(2), 561-590.Carhart, M. (1997). On persistence in mutual fund performance. Journal of Finance,52(1), 57-82.

Wermers, R. (2012). A Matter of Style: The causes and consequences of style drift in institutional portfolios. Working Paper. Robert H. Smith School of Business, Universityof Maryland.

Zahra, Shaker A. and Pearce, John a. (2015). "Boards of directors and corporate financial performance: A review and integrative model "Journal of management, 2, pp: 291-334 